\title{
The Influence of Investment Costs on Biogas Station Development and Their Impact on Greenhouse Gas Emissions from Czech Agriculture
}

\author{
J. Slaboch, P. Hálová
}

Faculty of Economics and Management, Czech University of Life Sciences Prague, Czech Republic

\begin{abstract}
The paper present the results for the influence of investment costs into biogas station on the amount of emissions from the agricultural sector. For the evaluation is applied structural analysis of major factors affecting the level of $\mathrm{CO}_{2}$ emissions from agriculture. Among these factors are: the number of animals (converted to livestock units), cost of investment in biogas plants, the quantity of nitrogen fertilizers and the total amount of $\mathrm{CO}_{2}$ emissions from agriculture. The results show that the investment costs haven't significant influence despite the correct direction of effect. Significant impact on $\mathrm{CO}_{2}$ emissions from agriculture have the numbers of animals (respectively cattle units). In the case of applications reviewed model from the Czech Republic to selected countries of the EU shows that the highest investment costs and also decrease $\mathrm{CO}_{2}$ equivalent emissions from agricultural biogas plants is in Germany. The high number of agricultural biogas plants is also evident in Italy and the United Kingdom. Investment costs are in these two countries in the range of 115 to 144 mld. CZK. Furthermore, it is evident that the significant investment costs are incurred by the smaller countries (Czech Republic, Slovakia, Belgium). Investment costs in this case are in the range $10-33$ mld. CZK.
\end{abstract}

\section{Keywords}

Biogas stations, $\mathrm{CO}_{2}$ emissions, animal waste, livestock numbers, linear regression model, investment costs.

Slaboch, J. and Hálová, P. (2016) "The Influence of Investment Costs on Biogas Station Development and Their Impact on Greenhouse Gas Emissions from Czech Agriculture", AGRIS on-line Papers in Economics and Informatics, Vol. 8, No. 4, pp. 143 - 151. ISSN 1804-1930. DOI 10.7160/aol.2016.080413.

\section{Introduction}

Because of significant increase in greenhouse gas emissions in the last decades, the pollution has become central global problem. Several countries including EU member states signed Kyoto protocol, which brings compulsory responsibilities. European Union declared to decrease greenhouse gas emissions by $20 \%$ on average compared to the level of 1990 by 2020 . One of the tools to achieve this goal is to increase the share of renewable resources in energy mix by $20 \%$ by 2020 (EEA 2013).

There are many factors influencing the level of $\mathrm{CO}_{2}$ emissions. The economic grows, number of inhabitants, technological changes, subsidies, institutional structures, transport, life style, international trade etc. are some of these determinants (Escolano and Rosa, 2005).

Agriculture generally including animal production significantly contributes to greenhouse gas emissions (Bellarby et al., 2013, Galloway et al., 2007, Herrero et al., 2011). As a result of this influence the agriculture community has undertaken to decrease emissions, which will lead to better environment protection. Over all agriculture emissions are 5,4-5,8 $\mathrm{GtCO}_{2} \mathrm{e}$, which is approximately $12 \%$ of total anthropogenic emissions (Tubiello et al., 2013).

When evaluating agriculture emission structure approximately $38 \%$ are accounted to nitrous oxid $\left(\mathrm{N}_{2} \mathrm{O}\right)$ from soil, $32 \%$ from ruminants $\left(\mathrm{CH}_{4}\right), 12 \%$ from biomass burning, $11 \%$ from rice production a $7 \%$ from manure management (Bellarby et al., 2008).

Majority of studies focuses on reduction of only one or several main types of greenhouse gas emissions from agriculture e.g. $\mathrm{CH}_{4}$ in publication by Petersen et al., 2005, $\mathrm{N}_{2} \mathrm{O}$ by Dämmgen a Hutchingsem 2008, $\Delta \mathrm{C}$ by Scott et al., 2002, $\mathrm{CO}_{2}$ from fossil fuels researched by Dalgaard et al 2001. Another 
possibility to reduce greenhouse gas emissions is to produce bioenergy (Jørgensen et al, 2005).

In the future it is possible to expect (according to individual predictions) an increase in agriculture product demand as a result of population growth, income growth and last but not least changing dietary preferences (higher meat, dairy product etc. consumption namely in Africa, South America and Asia). There have been many studies evaluating current and future situation, nonetheless specific conclusions vary according to chosen areas or agriculture practices taken into account (Yamaji et al., 2004, Oenema et al., 2005, Herrero et al., 2008).

Agriculture and mainly animal production is in global scale one of the most significant environmental polluters (Steinfeld et al., 2006) and biggest contributor to greenhouse gas emission increase (GHG), which causes climatic changes (Johnson et al., 2007).

Impact on emissions using animal waste in biogas plant is calculated, for example in Nigeria, where the use of animal waste amounted to a total production of $1,62 \times 109 \mathrm{~m} 3$ of biogas. Such a usage represents a decrease emissions by 683 ths. tonnes of $\mathrm{CO}_{2}$ per year. (Adeoti, Ayelegun and Osho, 2014)

Most emissions is currently produced by China. In rural areas of this state used by individual households small BPS (fermenter volume to $8 \mathrm{~m}^{3}$ ). Zhang, Wang and Song (2013) point to the fact that just the use of renewable resources (biogas) can represent the reduction potential of 1.25 tonnes of $\mathrm{CO}_{2}$ per household.

European commitment to reduce their emissions is a good opportunity for change in the share of individual sources in total energy production. In Sweden the use of biogas plants with a total production of $39 \mathrm{GWh}$ per year have reduced $\mathrm{CO}_{2}$ emissions by 32 ths. tonnes / year (if the classic coal plant was replaced by this power). (Amiri, Henning and Karlsson, 2013)

Individual instructions above to reduce emissions (mainly from agriculture) are very interesting from the point of view of environmental protection, on the other hand, are very expensive investment. For example, in India, in the years 2010-2011 was invested to the renewable sources 19 mld. dollars. Decrease in emissions due to these significant investment is estimated at 203 mil. tonnes of $\mathrm{CO}_{2}$ at an installed capacity of $24 \mathrm{GW}$ in 2012. (Mahesh and Shoba Jasmin, 2013).
Paper focuses on biogas stations (BGS) influence on $\mathrm{CO}_{2}$ emissions based on presumptions stated in methodology. In the future biogas will have increasingly higher importance as a factor leading to greenhouse gas emissions degrease, considering optimal cost oriented usage of possible sources and technologies. The results of studies imply the fact that it is an ideal combination of electricity and heat production mainly in the area of agglomeration or industrial enterprises. With this necessary condition it is possible (according to calculation based on life cycle - LCC, LCA) to save 198 Euro per 1 ton of $\mathrm{CO}_{2}$ equivalent using biogas instead of fossil fuels (Rehl, Muller, 2013).

The main goal of this paper is to determine the effect of the investment costs to biogas plants on the amount of emissions of equivalent of $\mathrm{CO}_{2}$ from agriculture.

\section{Materials and methods}

Econometric modelling is used for structural analysis, which derives significant factors effecting the amount of $\mathrm{CO}_{2}$ emissions produced by agriculture production including quantification of economic variables in the form of time series.

Data sets are for the period 2002 - 2014 and concern emissions (expressed) in $\mathrm{CO}_{2}$ for the area agriculture, and other branches in the framework of economy (energetics, industry, agriculture, LULUCF, wastes). Particular values in the area of agriculture are further (within the methodology) divided into two groups: enteric fermentation (concerning farm animals and their digestive processes), and further to the area land (concerning use of fertilizers and manure management). This key data were obtained from annual reports of CHMU for particular above mentioned groups ${ }^{1}$.

Numbers of livestock are obtained from Czech statistical office for individual categories (cattle, pigs, chicken). Those numbers are recalculated to cattle unit tin accordance with appendix n. 1 of Bill n. 377/2013 Col. $^{2}$

Install power is undertaken from statistics OTE, ERU ${ }^{3}$ and investment costs are calculated in accordance to recommend values by Dvořáček

\footnotetext{
${ }^{1}$ Available at web sites: http://portal.chmi.cz/files/portal/docs/uoco/ oez/nis/nis ta cz.html

2 available at web sites: http://eagri.cz/public/web/ws_content?conte ntKind $=$ image \&section $=1 \&$ id $=377-213 \mathrm{c} . \mathrm{pcx}$

3 OTE - Czech electricity and gas market operator, ERU - Energy Regulatory Office
} 
(2010), when coefficient 100000 CZK per $1 \mathrm{~kW}$ of install power is used.

For dynamic characterisation of chosen time series base and chain indexes including average rate of growth calculation are used.

Formula 1 - Base index $=\frac{\mathrm{Xi}}{\mathrm{Xz}} * 100$ (result in \%) when $\mathrm{Xz}$ is base value

Formula 2 - Chain index $=\frac{X i}{X i-1} * 100$ (result in \%)

Formula $3-$ Geometric mean $=\sqrt[n]{x 1 * x 2 * x 3 \ldots x n}$ ADF test (Augmented Dickey - Fuller) with null hypotheses $\mathrm{H} 0$ : data are non stationary, $\mathrm{H} 1$ : data are stationary, was used for data evaluation in the time series form.

The principle of the test is criteria calculation, which in order to accept $\mathrm{H} 0$ must be higher than the critical table value. Supporting variables in the form of time series were defined as nonstationary.

The classical regression analysis usage could lead to spurious regression, but considering a short time series a cointegration analysis cannot be used and it is not possible to determine a long-term relation among variables. However, for further mentioned models it is valid that the calculated residues are stationary.

For specification and quantification of significant determinants influence, economic quantities were selected which with their presence and effect will enable to estimate models verified in all respects, from the economic, statistical and econometrical point of view. These chosen variables are a part of below mentioned econometric model (1.1).

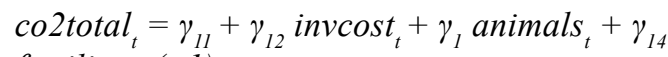
fertilizers $(t-1)+u_{1 t}$

when $u_{i t} \sim$ n.i.d. $\left(0, \sigma^{2}\right)$, for $\mathrm{i}=1,2 \ldots$

Authors will use estimations of the linear functions in the work. The estimations of linear function serves as an expression of direction and intensity of effect of predetermined variables from absolute viewpoint.

The submitted work defines several presumptions which it would like to confirm or rebut with the use of a linear regression model which will be applied in a structural analysis of air pollution measured with kt equivalent of $\mathrm{CO}_{2}$ coming from activities in non-agricultural area.

P1: growing cost investment to agricultural biogas stations (variable invcostt) will have a significant positive effect on pollution which will be shown by reduction of pollutants in the air,

P2: numbers of farm animals are a very important factor which will increase emissions Conversion to cattle units according to EAGRI Conversion of farm animals to a big cattle unit (cows, pigs, poultry) was realized according to coefficients published on web sites of the Ministry of Agriculture (appendix n. 1 of Bill n. 377/2013 Col.).

P3: an amount of used fertilizers in last period will have greater effect on the air pollution than numbers of farm animals because we can expect time delay between the usage industrial fertilisers and increase in $\mathrm{CO}_{2}$ emissions.

Subsequently, the estimated model used for comparison of emission reductions in selected EU countries (Austria, Belgium, France, Germany, Italy, Slovakia, Hungary, Great Britain and Poland). Investment costs in different countries are calculated according to the installed capacity, using the coefficient $(1 \mathrm{~kW}=100$ ths. CZK). Reducing emissions is calculated based on results for the Czech Republic, which are (ceteris paribus) be applied to other selected countries.

\section{Results and discussion}

The $\mathrm{CO}_{2}$ emission development in Czech Republic in accordance with biogas station construction (Graph 1) is possible to describe by elementary characteristics, chain and base indexes with initial year 2002. Their results are in Table 1.

With the help of chain index detecting interannual changes of individual data according to average rate of growth, we can detect almost $44 \%$ increase of investment costs. It is clear, that this situation occurs after implementation of EU fund subsidies. The fast rate of growth is in this case supported by decision of ERU (Energy Regulatory Office) concerning purchase prices and green bonuses of this renewable resource. Biogas stations connected to the end of 2011 obtain $4120 \mathrm{CZK}$ per $1 \mathrm{MWh}$ (purchase price). Biogas stations connected from 1.1.2012 till 31.12.2012 obtain the sum of $3550 \mathrm{CZK}$ per $1 \mathrm{MWh}$ (purches price). Larger biogas stations (over $550 \mathrm{~kW}$ of installed power) have from 1.1.2013 purchase price only $3040 \mathrm{CZK}$ per $1 \mathrm{MWh}$. As a result of significant increase in renewable recourses (solar, wind etc.) there are no set purchase prices of electricity for biogas stations connected in 2016. Unambiguously positive and different development 


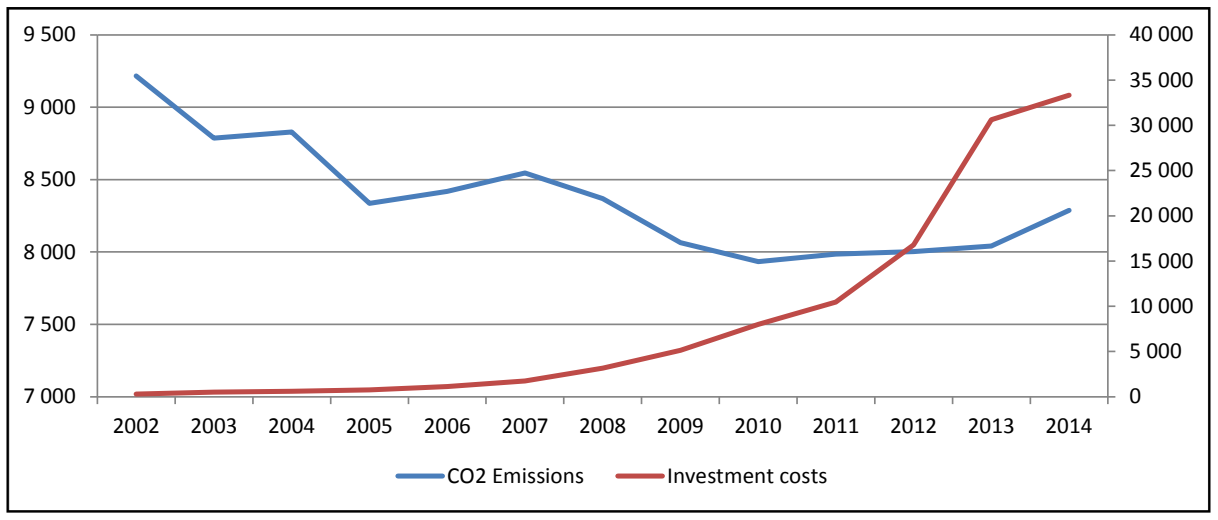

Source: Authors - own processing

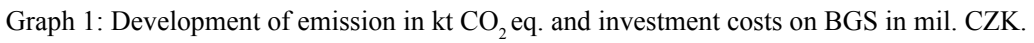

\begin{tabular}{|c|c|c|c|}
\hline chain index & base index & chain index & base index \\
\hline Investment cost & Investment cost & $\mathrm{CO}_{2}$ emissions & $\mathrm{CO}_{2}$ emissions \\
\hline 1.73630137 & 1.73630137 & 0.953411 & 0.953411 \\
\hline 1.17357002 & 2.037671233 & 1.004978 & 0.958158 \\
\hline 1.253781513 & 2.554794521 & 0.943955 & 0.904458 \\
\hline 1.516085791 & 3.873287671 & 1.010084 & 0.913579 \\
\hline 1.532272325 & 5.934931507 & 1.014992 & 0.927276 \\
\hline 1.828043855 & 10.84931507 & 0.979354 & 0.908132 \\
\hline 1.617424242 & 17.54794521 & 0.963691 & 0.875158 \\
\hline 1.56323185 & 27.43150685 & 0.983665 & 0.860863 \\
\hline 1.30474407 & 35.79109589 & 1.006624 & 0.866565 \\
\hline 1.604344082 & 57.42123288 & 1.002025 & 0.86832 \\
\hline 1.825251983 & 104.8082192 & 1.004844 & 0.872526 \\
\hline 1.089367403 & 114.1746575 & 1.030661 & 0.899278 \\
\hline Geometric mean & & Geometric mean & \\
\hline 1.439708583 & & 0.991867 & \\
\hline
\end{tabular}

Source: Author - own calculation

Table 1: Changes of investment costs and $\mathrm{CO}_{2}$ emissions in time.

can be detected for emissions, which decreased on average by $1 \%$ in the actual period.

Before estimation of specific linear regression model multicolinearity between explanatory variables was detected with the help of correlation matrix. It proved high measure of association between investment costs and fertilizers and between number of livestock and fertilizers.

In this case it is not possible to separate individual variable influence and their effect is collective. This conclusion corresponds with the fact, that animal and plant production are closely connected. With the help of VIF test multicolinearity problem was confirmed for variables costs and fertilizers. The value of test criteria VIF exceeded recommended number 10. Model estimations stated in Table 2 take into account detected $1^{\text {st }}$ order negative autocorrelation of residual by heteroscedasticity and autocorrelation consistent errors (hac errors).

From economic point of view investment costs growth confirm presumption P1, which was stated in methodology of work, but statistic verification speaks about inversion. The variable does not have statistically significanteffect, despite of this influence direction being correct. If investment costs to biogas stations increase, $\mathrm{CO}_{2}$ emission decrease. The only significant parameters appear to be according to presumptions animal numbers and quantity of fertilizers one year before. From introduced results it is not possible to interpret, which variable has the most significant effect on $\mathrm{CO}_{2}$ changes caused by multicolinearity. One of possibilities how to remove unwanted multicolinearity influence 


\begin{tabular}{|l|c|c|c|c|c|}
\hline & coefficient & standard error & t-share & p-value & \\
\hline const & 957.565 & 1289.25 & 0.7427 & 0.47889 & \\
\hline & -0.00397 & 0.00649 & -0.6103 & 0.55858 & \\
\hline animals & 0.00298 & 0.00024 & 12.4650 & $<0.04304$ & $* * *$ \\
\hline fertilizers_1 & 9.6471 & 4.036 & 2.4021 & 0.00001 & $* *$ \\
\hline
\end{tabular}

Note: Dependent variable: co2total

Coefficient determination

0.942

Adj. coefficient of determination

D-W statistics

Source: author - calculations in the software Gretl

Table 2: Estimation of linear regression model.

\begin{tabular}{|l|c|c|c|c|c|}
\hline & coefficient & standard error & t-share & p-value & \\
\hline const & 4905.2 & 803.331 & 6.1061 & 0.00049 & $* * *$ \\
\hline d_invcost & -0.00296 & 0.01593 & -0.1857 & 0.85796 & \\
\hline animals & 0.002013 & 0.000472 & 4.2682 & 0.00371 & $* * *$ \\
\hline d_fertilizers_1 & 8.21751 & 5.46888 & 1.5026 & 0.17664 & \\
\hline
\end{tabular}

Note: Dependent variable: co2total

Coefficient determination

0.82

Adj. coefficient of determination $\quad 0.75$

D-W statistics

1.57

Source: author - calculations in the software Gretl

Table 3: Estimation of linear regression model after multicolinearity removal.

is primary data transformation to first differences form. It was provided for variable investment costs and fertilizers. Conditioned variables in correlation matrix and VIF test do not prove multicolinearity anymore.

Newly estimated model, which results are in Table 3, provides information which can be interpreted individually. Variable investment costs were included in the model as a significant explanatory variable. In this period was proved, that this variable is statistically insignificant. For this reason, this variable (investment cost) in not further interpreted. It is possible to say, that unit increase of animal number causes the increase of $\mathrm{CO}_{2}$ emissions by $0.002013 \mathrm{kt}$. Construction and good management of BGS unambiguously support the elimination of pollutions in the greenhouse gas form arising from animal production. Expressed relatively in the form of elasticity Table 4 shows that increase of animal unit by $1 \%$ brings increase of emissions by almost $0.5 \%$.

\begin{tabular}{|l|c|}
\hline & Elasticity in \% \\
\hline BGS & -0.0031 \\
\hline animals & 0.41 \\
\hline fertilizers & 0.25 \\
\hline
\end{tabular}

Source: Author - own calculation

Table 4: Elasticities estimation of total $\mathrm{CO}_{2}$ emissions model.
Based on the verified model for the Czech Republic is also made a comparison with selected EU countries. The calculation is based on the calculation of investment costs in other countries (calculation is according with the methodology) then is estimated emissions reductions based on the results of the Czech Republic (see Table 5).

\begin{tabular}{|l|r|r|}
\hline & $\begin{array}{r}\text { Investment } \\
\text { cost (mil. Kč) }\end{array}$ & $\begin{array}{c}\text { Impact on emissions } \mathrm{CO}_{2} \\
\text { from agriculture (kt) }\end{array}$ \\
\hline Austria & 8100 & -23.9760 \\
\hline Belgium & 17820 & -52.7472 \\
\hline France & 29720 & -87.9712 \\
\hline Germany & 385900 & -1142.2640 \\
\hline Hungary & 6140 & -18.1744 \\
\hline Poland & 20930 & -61.9528 \\
\hline Italy & 115470 & -341.7912 \\
\hline Slovakia & 10170 & -30.1032 \\
\hline United Kingdom & 144000 & -426.2400 \\
\hline Czech Republic & 33339 & -98.6834 \\
\hline
\end{tabular}

Source: Author - own calculation

Table 5: Investment cost and their impact on emissions in selected countries EU (2014).

The results show that the sharpest reductions takes place in Germany (a fall of $1142 \mathrm{kt} \mathrm{CO}_{2}$ equivalent emissions). In this country the biogas plant is widespread, it is also interesting value investment costs (100 ths. CZK per $1 \mathrm{~kW}$ of electricity), 
amounting to 386 mld. CZK. The high number of agricultural biogas plants is also evident in Italy and the United Kingdom. Investment costs in these two countries, ranging from 115 to $144 \mathrm{mld}$. CZK. Table 5 shows that the significant investment costs are incurred by the smaller countries (Czech Republic, Slovakia, Belgium). Investment costs in this case are in the range 10-33 mld. CZK.

\section{Conclusion}

Exponential growth of investment costs for BGS construction and their quantity was impulse for researching this situation and looking for main determinants effecting them. With the help of chain index detecting interannual changes of individual data according to average rate of growth, we can detect almost $44 \%$ increase of investment costs. It is clear, that this unsustainable situation occurs after implementation of $\mathrm{EU}$ fund subsidies. Unambiguously positive and different development can be detected for emissions, which decreased on average by $1 \%$ in the actual period.

Since 2005, EU has managed to decrease its aggregated emissions by $3.1 \%$. But, the results from this study show, that each EU member state performs very differently in emissions intensities. Even more, the emission intensity results show an alarming tendency of increase in most of the EU member states, which indicates that the measured changes in aggregate agricultural emissions rates are misleading. (Dace and Blumberga, 2016)

In Italy consider of mathematical modeling of the impacts of greening (recent CAP reform 2014-2020). In this study they estimated the potential environmental benefits from greening in terms of GHG emissions in four regions of Northern Italy. The model estimates a reduction in $\mathrm{CO}_{2}$ emissions of about $2 \%$. Emissions from nitrous oxide show a decrease of $2.1 \%$ and the reduction in the methane is about $0.4 \%$ compared to the observed scenario. (Solazzo et. al., 2016)

From economic point of view investment costs growth confirm presumption $\mathrm{P} 1$, which was stated in methodology of work, but statistic verification speaks about inversion. The variable does not have statistically significant effect, despite of this influence direction being correct. If investment costs to biogas stations increase, $\mathrm{CO}_{2}$ emission decrease. The only significant parameters appear to be according to presumptions animal numbers and quantity of fertilizers one year before.
From introduced results it is not possible to interpret, which variable has the most significant effect on $\mathrm{CO}_{2}$ changes caused by multicolinearity. Therefore it is not possible to react adequately to presumption $\mathrm{P} 2$ and $\mathrm{P} 3$.

Newly estimated model, which results are in Table 3, provides information which can be interpreted individually. It is possible to say, that unit increase of animal number causes the increase of $\mathrm{CO}_{2}$ emissions by $0.002013 \mathrm{kt}$. Construction and good management of BGS unambiguously support the elimination of pollutions in the greenhouse gas form arising from animal production by using their waste. Expressed relatively in the form of elasticity Table 4 shows that increase of animal unit by $1 \%$ brings increase of emissions by almost $0.5 \%$. It is possible to evaluate the reaction as non elastic. Number of livestock significantly influence emission quantity however their forceful decrease does not come to effect in the end.

Suitable technology for animal and plant waste management can provide sources for plant production which does not need to use mineral fertilizers to such extend. In this case sludge (liquor) and digestate from biogas stations is used. According to legislation digestate is type organic fertilizer if it complies with the condition of minimum of $25 \%$ burnable matter in dry substance and minimum content of nitrogen $0.6 \%$ in dry substance and it falls into the category of fertilizers with rapid release nitrogen.

Usage and digestate dose as fertilizer is comparable to slurry considering the amount of nutrients mainly nitrogen. Similar principles defined for fertilizing with liquid organic fertilizers are valid for their application. (Fuksa and Hakl, 2009)

Construction of BGS is long time investment which becomes profitable approximately in ten years. Mužík and Abrham (2006) consider the return rate of investment in 5 years to be very good, in 10 years to be acceptable. This results are confirmed by other studies by Wu et. al, 2016; Mel et. al, 2015 or Kang et. al, 2014. If animal production is further reduced and unstable situation namely in milk production is deepened, the question is whether this initially valuable idea does not paralyse the agriculture enterprises in the future.

In the case of applications reviewed model from the Czech Republic to selected countries of the EU shows that the highest investment costs and also decrease $\mathrm{CO}_{2}$ equivalent emissions from agricultural biogas plants is in Germany. 
The high number of agricultural biogas plants is also evident in Italy and the United Kingdom. Investment costs are in these two countries in the range of 115 to $144 \mathrm{mld}$. CZK. Furthermore, it is evident that the significant investment costs are incurred by the smaller countries (for example Czech Republic, Slovakia and Belgium). Investment costs in this case are in the range 10-33 mld. CZK. In the framework of the emission reduction is $\mathrm{CR}$ $4^{\text {th }}$ place (-98 kt $\mathrm{CO}_{2}$ equivalent) after Germany
(-1142 $\mathrm{kt} \mathrm{CO}_{2}$ equivalent), United Kingdom (-426 kt $\mathrm{CO}_{2}$ equivalent) and Italy (-341 $\mathrm{kt} \mathrm{CO}_{2}$ equivalent).

\section{Acknowledgements}

This paper was supported by grant IGA FEM No. 20131030 - Alternatives for biomass processing and animal waste in biogas plants and their impact on the economics of enterprises.

\section{Corresponding author:}

Ing. Josef Slaboch, Ph.D.

Department of Economics, Faculty of Economics and Management, Czech University of Life Sciences Prague, Kamýcká 129, 16521 Prague 6, Czech Republic E-mail: jslaboch@pef.czu.cz

\section{References}

[1] Adeoti, O., Ayelegun, T. A. and Osho, S. O. (2014) "Nigeria biogas potential from livestock manure and its estimated climate value", Renewable and sustainable energy reviews, Vol. 37, pp. 243-248. ISSN 1364-0321. DOI 10.1016/j.rser.2014.05.005.

[2] Amiri, S., Henning, D. and Karlsson B. G. (2013) "Simulation and introduction of a CHP plant in a Swedish biogas system", Renewable energy, Vol. 49, pp. 242-249. ISSN 0960-1481. DOI 10.1016/j.renene.2012.01.022.

[3] Bellarby, J., Foereid, B., Hastings, A. and Smith, P. (2008) „Cool Farming: Climate Impacts of Agriculture and Mitigation Potential", Greenpeace International, Amsterdam, The Netherlands. [Online]. Available: http://www.greenpeace.org /international/Global/international/planet-2/ report/2008/1/cool-farming-fullreport.pdf [Accessed: 23 Jan. 2015].

[4] Bellarby, J., Tirado, R., Leip, A., Weiss, F., Lesschen, J. P. and Smith, P. (2013) „Livestock greenhouse gas emissions and mitigation potential in Europe“, Global Change Biology, Vol. 19, pp. 3-18. ISSN 1365-2486. DOI 10.1111/j.1365-2486.2012.02786.x.

[5] Dace, E. and Blumberga, D. (2016) "How do 28 European Union Member States perform in agricultural greenhouse gas emissions? It depends on what we look at: Application of the multi-criteria analysis", Ecological Indicators, Vol. 71, pp. 352-358. ISSN 1470-160X. DOI 10.1016/j.ecolind.2016.07.016

[6] Dalgaard, T., Halberg, N. and Porter, J. R. (2001) “A model for fossil energy use in Danish agriculture used to compare organic and conventional farming”, Agriculture, Ecosystems and Environment, Vol. 87, No. 1, pp. 51-65. ISSN 0167-8809. DOI 10.1016/S0167-8809(00)00297-8.

[7] Dämmgen, U. and Hutchings, N. J. (2008) "Emissions of gaseous nitrogen species from manure management: a new approach", Environmental Pollution, Vol. 154, No. 3, pp. 488-497. ISSN 0269-7491. DOI 10.1016/j.envpol.2007.03.017.

[8] Dvořáček, T. (2010) “Ekonomika bioplynových stanic pro zpracování BRO” (Economics of biogas stations for BRO processing, in Czech), Biom.cz. [Online]. Available: http://biom.cz/cz/ odborne-clanky/ekonomika-bioplynovych-stanic-pro-zpracovani-bro [Accessed: 14 July 2016]. ISSN 1801-2655.

[9] Escolano, V. A. and Rosa, E. P. (2005) "Análisis de las emisiones de $\mathrm{CO}_{2}$ y sus factores explicativos en las deferentes áreas del mundo", Revista de Economía Crítica, Vol. 4, pp. 17-37. ISSN 1696-0866. 
[10] EEA European Environment Agency (2013) „Trends and Projections in Europe 2013“, EEA European Environment Agency, Aug. 2006. [Online]. Available: http://www.eea.europa.eu/ publications/trends-and-projections-2013 [Accessed: 23 Jan. 2015].

[11] Fuksa, P. and Hakl, J. (2009) "Využití pícních plodin pro výrobu bioplynu" (Use of fodder crops for bio-gas production, in Czech), Biom.cz. [Online]. Available: http://biom.cz/cz/odborne-clanky/ vyuziti-picnich-plodin-pro-vyrobu-bioplynu [Accessible: 28 July 2016]. ISSN 1801-2655.

[12] Galloway, J. N., Burke, M., Bradford, G. E., Naylor, R., Falcon, W., Chapagain, A. K., Gaskell, J. C., McCullough, E., Mooney, H. A., Oleson, K. L. L., Steinfeld, H., Wassenaar, T. and Smil, V. (2007) „International trade in meat: the tip of the pork chop“, Ambio, Vol. 36, pp. 622-629. DOI: 10.1579/0044-7447(2007)36[622:ITIMTT]2.0.CO;2.

[13] Herrero, M., Gerber, P., Vellinga, T., Garnett, T., Leip, A., Opio, C., Westhoek, H., Thornton, P., Olesen, J., Hutchings, N., Montgomery, H., Soussana, J., Steinfeld, H. and McAllister, T. (2011) „Livestock and greenhouse gas emissions: the importance of getting the numbers right“, Animal Feed Science and Technology, Vol. 166 - 167, pp. 779-782. ISSN 0377-8401. DOI 10.1016/j.anifeedsci.2011.04.083.

[14] Herrero, M., Thornton, P. K., Kruska, R. and Reid, R. S. (2008) "Systems dynamics and the spatial distribution of methane emissions from African domestic ruminants to 2030", Agriculture Ecosystems and Environment, Vol. 126, No. 1-2, pp. 122-137. ISSN 0167-8809. DOI 10.1016/j.agee.2008.01.017.

[15] Johnson, J. M. F., Franzluebbers, A., Weyers S. L. and Reicosky, D. C. (2007) "Agricultural opportunities to mitigate greenhouse gas emissions", Environmental Pollution, Vol. 150, pp. 107-124. ISSN 0269-7491. DOI 10.1016/j.envpol.2007.06.030.

[16] Jørgensen, U., Dalgaard T. and Kristensen E. S. (2005) "Biomass energy in organic farming - the potential role of short rotation coppice", Biomass and Bioenergy, Vol. 28, pp. 237-248. ISSN 0961-9534. DOI 10.1016/j.biombioe.2004.08.006.

[17] Kang, J. Y., Kang, D. W., Kim, T. S. and Hur, K. B. (2014) "Economic evaluation of biogas and natural gas co-firing in gas turbine combined heat and power systems", Applied thermal engineering, Vol.70, No.1,pp.723-731.ISSN1359-4311.DOI10.1016/j.applthermaleng.2014.05.085.

[18] Mahesh, A. and Shoba Jasmin, K. S. (2013) "Role of renewable energy investment in India: An alternative to $\mathrm{CO}_{2}$ mitigation", Renewable and sustainable energy reviews, Vol. 26, pp. 414-424. ISSN 1364-0321. DOI 10.1016/j.rser.2013.05.069.

[19] Mel, M., Young, A. S., Ihsan, S. I. and Setyobudi, R. H. (2015) "Simulation study for economic analysis of biogas production from agricultural biomass", Energy Procedia, Vol. 65, pp. 204-214. ISSN 1876-6102. DOI 10.1016/j.egypro.2015.01.026.

[20] Mužík, O. and Abrham, Z. (2006) "Economic modelling of biogas production”, Conference in: Management of Production Systems with support of Information Technologies and Control Engineering. Nitra, 2006, pp. 196-201. ISBN 80-8069-743-4.

[21] Oenema, O., Wrage, N., Velthof, G., Groenigen, J., Dofing, J. and Kuikman, J. (2005) "Trends in global nitrous oxide emissions from animal production systems", Nutrient Cycling in Agroecosystems, Vol. 72, pp. 51-65. ISSN 1385-1314.

[22] Petersen, S. O., Amon, B. and Gattinger, A. (2005) "Methane oxidation in slurry storage surface crusts", Journal of Environmental Quality, Vol. 34, pp. 455-461. ISSN 1537-2537.

[23] Rehl, T. and Muller, J. (2013) " $\mathrm{CO}_{2}$ abatement costs of greenhouse gas (GHG) mitigation by different biogas conversion pathways", Journal of Environmental Management, Vol. 114, pp. 13-25. ISSN 0301-4797. DOI 10.1016/j.jenvman.2012.10.049. 
[24] Scott, N. A., Tate, K. R., Giltrap, D. J., Tattersall, C., Smith, Wilde, H. R., Newsome, P. J. F. and Davis, M. R (2002) "Monitoring land-use change effects on soil carbon in New Zealand: quantifying baseline soil carbon stoce", Environmental Pollution, Vol. 116, No. 1, pp. 167-186. ISSN 0269-7491. DOI 10.1016/S0269-7491(01)00249-4.

[25] Solazzo, R., Donati, M., Tomasi, L. and Arfini, F. (2016) "How effective is greening policy in reducing GHG emissions from agriculture? Evidence from Italy", Science of The Total Environment, Vol. 573, pp. 1115-1124. ISSN 0048-9697. DOI 10.1016/j.scitotenv.2016.08.066.

[26] Steinfeld, H., Gerber, P., Wassenaar, T., Castel, V. and Rosales, M. (2006) “Livestock's long shadow - Environmental issues and options", Food and Agriculture organization. ISBN 978-92-5-105571-7.

[27] Tubiello, F. N., Cóndor-Golec, R. D., Salvatore, M., Piersante, A., Federici, S., Ferrara, A., Rossi, S., Flammini, A., Cardenas, C., Biancalani, R., Jacobs, H., Prasula, P. and Prosperi P. (2015) „Estimating Greenhouse Gas Emissions in Agriculture: a Manual to Address Data Requirements for Developing Countries", Food and Agriculture Organization of the United Nations, Rome. ISBN 978-92-5-108674-2.

[28] Wu, B., Zhang, X., Shang, D., Bao, D., Zhang, S. and Zheng, T. (2016) "Energetic-environmentaleconomic assessment of the biogas system with three utilization pathways: combined heat and power, biomethane and fuel cell", Bioresource technology. Vol. 214, pp. 722-728. ISSN 0960-8524. DOI 10.1016/j.biortech.2016.05.026.

[29] Yamaji, K., Ohara, T. and Akimoto, H. (2004) "Regional-specific emission inventory for $\mathrm{NH}_{3}, \mathrm{~N}_{2} \mathrm{O}$, and $\mathrm{CH}_{4}$ via animal farming in south, southeast, and East Asia", Atmospheric Environment, Vol. 38, pp. 7111-7121. ISSN 1352-2310. DOI 10.1016/j.atmosenv.2004.06.045.

[30] Zhang, L. X., Wang, C. B. and Song, B. (2013) "Carbon emission reduction potential of a typical household biogas system in rural China", Journal of cleaner production, Vol. 47, pp. 415-421. ISSN 0959-6526. DOI 10.1016/j.jclepro.2012.06.021. 